\title{
Multiple hepatic abscesses following Yersinia enterocolitica septicemia
}

\author{
Franco Colizza, MD, Serge LePAge, MD, JEAN-FrançoIs LAJOIE, MD, CSPQ, FRCPC, \\ RAYMOND DUPERVAL, MD, CSPQ, FRCPC, ANDRE MARCOUX, MD, CSPQ, FRCPC, \\ JACQUES MONGEAU, MD, CSPQ, DENIS BERGERON, MD, CSPQ, FRCPC
}

\begin{abstract}
Septicemia from Yersinia enterocolitica is unusual. Hepatic involvement occurring in this clinical setting is a rare complication. A case of a 64-year-old man who developed septicemia from $Y$ enterocolitica is reported. Abdominal ultrasound and computerized axial tomography scan revealed multiple defects in liver parenchyma compatible with abscesses. After treatment with intravenous aminoglycosides followed by trimethoprim-sulfamethoxazole, recovery was complete. General considerations regarding the manifestations and pathogenesis of $Y$ enterocolitica are discussed, with a review of the literature. Can J Gastroenterol 1990;4(5):179-183
\end{abstract}

Key Words: Hepatic abscesses, Yersinia enterocolitica septicemia

\section{Abcès hépatiques multiples résultant d'une septicémie à Yersinia enterocolitica}

RESUME: La septicémie provoquée par Yersinia enterocolitica est inhabituelle. Latteinte hépatique se produisant dans ce cadre clinique est une complication rare. On rapporte le cas d'un homme de 64 ans atteint d'une septicémie due à $Y$ enterocolitica. L'échographie et la TDM ont révélé de multiples anomalies du parenchyme hépatique indiquant la présence d'abcès. Il y a eu guérison complète après un traitement aux aminosides intraveineux suivi de triméthoprimesulfaméthoxazole. Les considérations générales relatives aux manifestations et à la pathogenèse d'Y enterocolitica sont examinées et incluent une revue de la littérature.

Centre Hospitalier Universitaire de Sherbrooke, Sherbrooke, Quebec

Correspondence and reprints: Dr Jean-François LaJoie, Centre Hospitalier Universitaire de

Sherbrooke, 3001, 12e Avenue N, Sherbrooke, Quebec J1H 5N4. Telephone (819) 563-5555

Received for publication July 20, 1989. Accepted January 31, 1990
Y

ERSINIA ENTEROCOLITICA IS A

Gram-negative organism becoming more frequently recognized in human infections. Seventeen serotypes and five biotypes have been identified (1). In Canada, $80 \%$ of infections are caused by serotype $0: 3$ biotype 4 , although an outbreak in Montreal was caused by serotype 0:5,27 (2). In the United States, serotype $0: 8$ is predominant (3).

$Y$ enterocolitica infection produces a variety of clinical manifestations. The one most commonly encountered is acute gastroenteritis, found in all age groups. Mesenteric lymphadenitis and acute terminal ileitis are other well known entities associated with yersinia infections, especially in young people $(4,5)$. Septicemia is a rare complication with approximately 100 cases reported in the literature (6). Few reports exist of hepatic abscesses; mortality from this complication is high (7). However, early recognition and appropriate antibiotic treatment may alter the prognosis. 


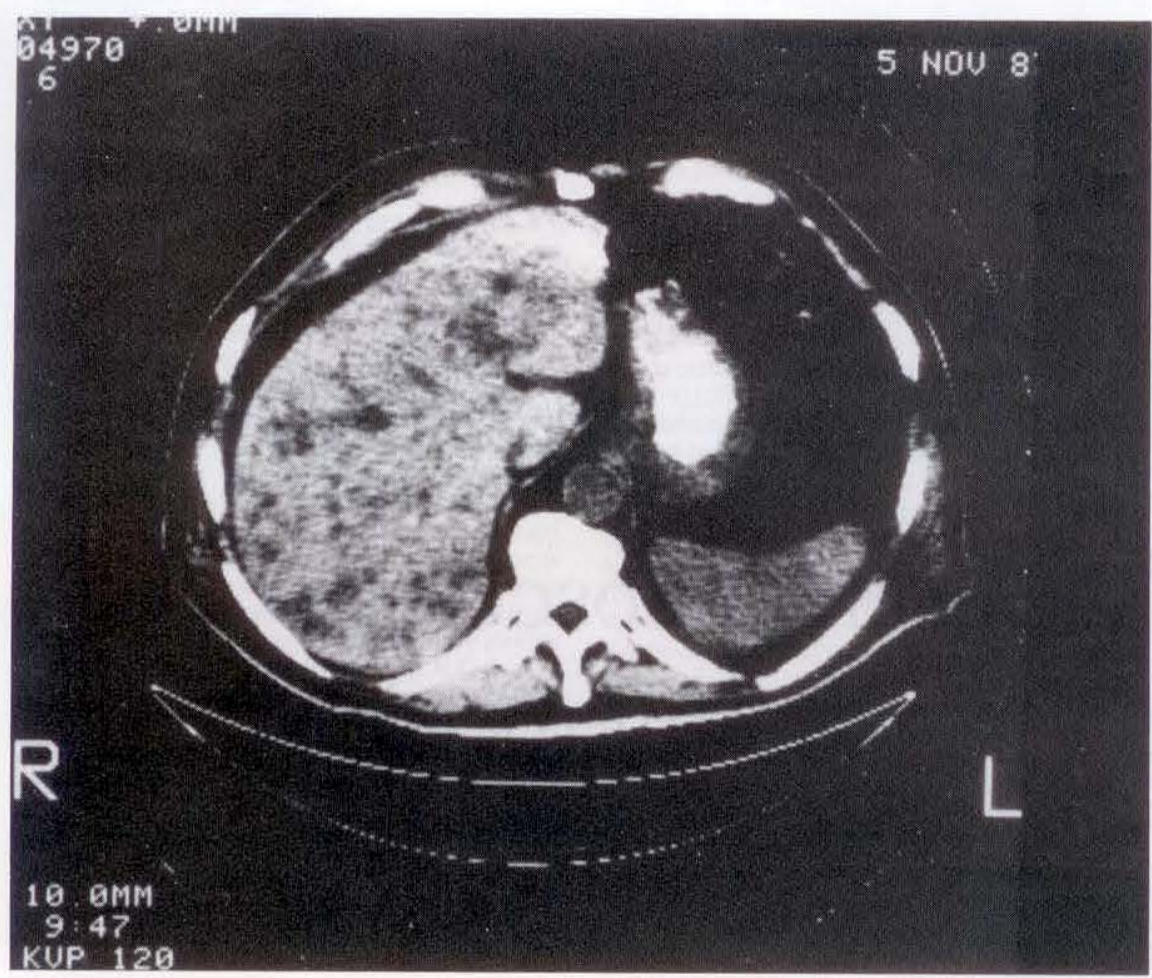

Figure 1) Abdominal computerized axial tomography scan. Multiple hypodense lesions of variable size measuring $u p$ to $I \mathrm{~cm}$ are scattered throughout the liver
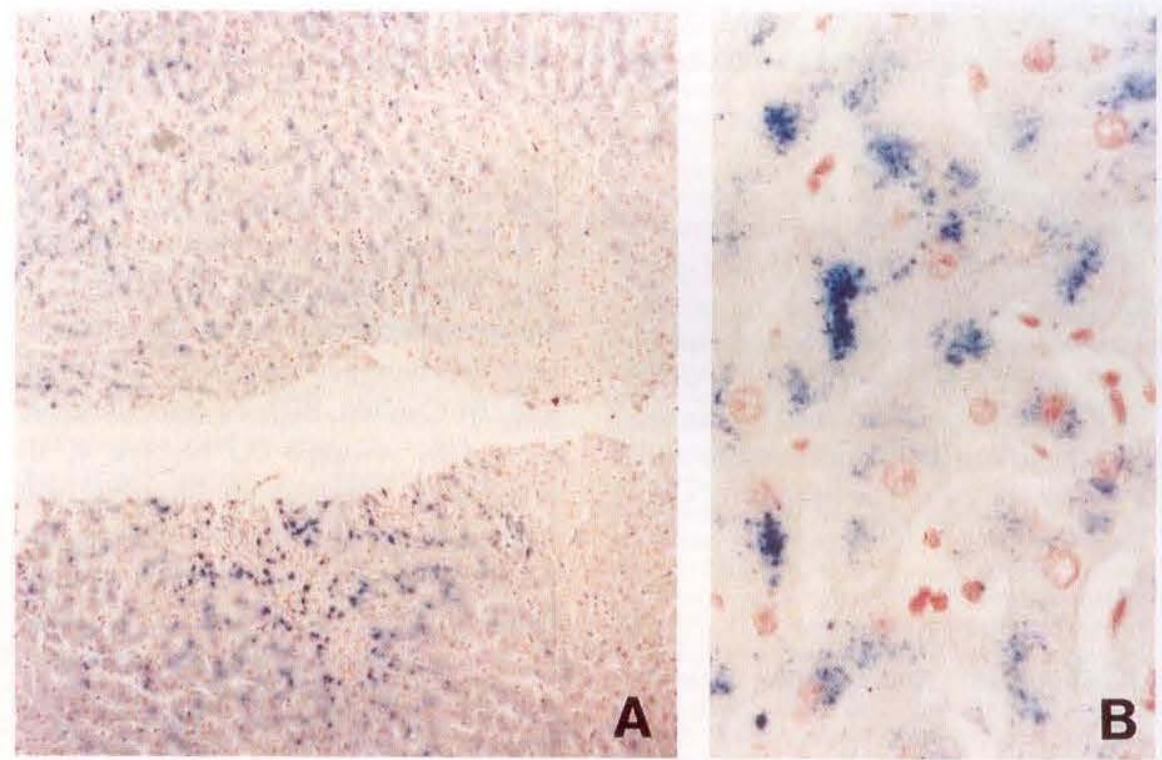

Figure 2) Markedly increased hemosiderin pigment within the cytoplasm of hepatocytes. (Prussian blue $\mathbf{A} \times 40, \mathbf{B} \times 270$ )

\section{CASE PRESENTATION}

A 64-year-old man from Bretagne in Northern France with no pertinent past medical history was admitted to hospital with a six month history of progressive weakness, $8 \mathrm{~kg}$ weight loss, polyuria and polydipsia. Twenty-four hours prior to admission the patient developed fever and was brought in in a comatose state. Initial evaluation revealed a nonketotic hyperosmolar state (blood sugar $70 \mu \mathrm{mol} / \mathrm{L}$ ) which improved with therapy. However, fever up to $40^{\circ} \mathrm{C}$ persisted and diarrhea developed. Three blood cultures drawn on admission later grew $Y$ enterocolitica (serotype 0:3 biotype 4).

Cefoxitin $2 \mathrm{~g}$ intravenously every $6 \mathrm{~h}$ was started. Clinical state improved and the patient was afebrile $72 \mathrm{~h}$ later. On the fifth day, jaundice and hepato. megaly developed. The patient was transferred to the authors' institution.

Physical examination disclosed an asthenic but nontoxic patient. Jaundice without hyperpigmentation was noted. Temperature was $37.2^{\circ} \mathrm{C}$, pulse 88 beats/min and blood pressure 125/75 mmHg. Abdominal examination revealed a palpable liver $7 \mathrm{~cm}$ below the costal margin and $15 \mathrm{~cm}$ on percussion without evidence of splenomegaly. Laboratory tests revealed: hemoglobin $144 \mathrm{~g} / \mathrm{L}$; leukocyte count 27,920 with $87 \%$ neutrophils; aspartate aminotransferase $75 \mathrm{iu} / \mathrm{L}$ (normal 0 to 20 ); alanine aminotransferase $89 \mathrm{iu} / \mathrm{L}$ (normal 0 to 29); alkaline phosphatase 645 iu/L (normal 45 to 107); total bilirubin $55 \mu \mathrm{mol} / \mathrm{L}$ (normal 0 to 17 ); direct fraction $24 \mu \mathrm{mol} / \mathrm{L}$ (normal 0 to 10 $\mu \mathrm{mol} / \mathrm{L}$ ); ferritin $2754 \mu \mathrm{g} / \mathrm{L}$ (normal 42 to 313 ); plasma iron $5.5 \mu \mathrm{mol} / \mathrm{L}$ (normal 13 to 35 ); total iron binding capacity $21.14 \mu \mathrm{mol} / \mathrm{L}$ (normal 44.75 to 71.60 ); and iron saturation $26.3 \%$. Specific HLA-typing wasn't done.

Abdominal ultrasound was performed which confirmed hepatomegaly with multiple hypoechogenic lesions. Multiple hepatic abscesses were diag. nosed. Cefoxitin was changed for gentamicin $(4.5 \mathrm{mg} / \mathrm{kg} /$ day $)$. Abdominal computerized axial tomography scan confirmed multiple hypodense lesions throughout the liver parenchyma consistent with liver abscesses (Figure 1). Repeat blood and stool cultures done after one week of antibiotic therapy failed to reveal $Y$ enterocolitica. Upper and lower gastrointestinal series did not show evidence of ileitis.

After two weeks of treatment, a fineneedle liver biopsy (Figure 2) was performed in consideration of the occurrence of diabetes mellitus, $Y$ enterocolitica septicemia and elevated ferritin in a patient of Breton origin. Histologic findings revealed diffuse increased parenchymal iron stores (grade 3 on a scale of 0 to 4) (8) without signs of tissue damage or any particular zonal distribution. No signs of cirrhosis were evident.

The patient's clinical status im- 
TABLE 1

Yersinia enterocolitica and hepatic abscesses reported

\begin{tabular}{|c|c|c|c|c|c|c|c|}
\hline Author & Year & Sex & $\begin{array}{c}\text { Age } \\
\text { (years) }\end{array}$ & Underlying condition & Treatment & Diagnosis & Outcome \\
\hline Khanna (51) & 1989 & M & 37 & Diabetes & $\begin{array}{l}\text { Gentamicin } \\
\text { Clindamicin } \\
\text { Trimethoprim- } \\
\text { sulfamethoxazole }\end{array}$ & $\begin{array}{l}\text { Computed tomo- } \\
\text { graphy scan }\end{array}$ & Survived \\
\hline Cauchie (52) & 1987 & M & 47 & Hemochromatosis & $\begin{array}{l}\text { Cefuroxine } \\
\text { Ampicillin }\end{array}$ & $\begin{array}{l}\text { Ultrasound } \\
\text { Biopsy }\end{array}$ & Survived \\
\hline Leighton (6) & 1987 & $F$ & 71 & Iron therapy & $\begin{array}{l}\text { Gentamicin } \\
\text { Trimethoprim- } \\
\text { sulfamethoxazole }\end{array}$ & $\begin{array}{l}\text { Ultrasound } \\
\text { Biopsy }\end{array}$ & Survived \\
\hline Abalain-Colloc (49) & 1986 & M & 61 & Diabetes & Thiamphenicol & $\begin{array}{l}\text { Ultrasound } \\
\text { Biopsy }\end{array}$ & Survived \\
\hline Beeching (48) & 1985 & M & 72 & Hemosiderosis & - & Autopsy & Dead \\
\hline Van Lier (47) & 1983 & M & 38 & Hemochromatosis & - & - & Dead \\
\hline Fothergill (46) & 1982 & M & 46 & Diabetes & Gentamicin & $\begin{array}{l}\text { Ultrasound } \\
\text { Liver biopsy }\end{array}$ & Survived \\
\hline Viteri (45) & 1981 & M & 71 & Diabetes & $\begin{array}{l}\text { Cefoxitin \& } \\
\text { tetracycline }\end{array}$ & $\begin{array}{l}\text { Gallium scan } \\
\text { Laparotomy }\end{array}$ & Survived \\
\hline Imhoof (44) & 1980 & M & 48 & Hemochromatosis & & - & Dead \\
\hline Ryan (43) & 1979 & M & 3 months & - & Ampicillin & $\begin{array}{l}\text { Technetium } 99 \mathrm{~m} \\
\text { scan \& laparotomy }\end{array}$ & Survived \\
\hline Mantse (42) & 1978 & M & 64 & Diabetes & Gentamicin & $\begin{array}{l}\text { Gallium scan } \\
\text { Laparotomy }\end{array}$ & Survived \\
\hline Bottone (35) & 1977 & $M$ & $\begin{array}{l}60 \\
69\end{array}$ & $\begin{array}{l}\text { Cirrhosis } \\
\text { Cirrhosis }\end{array}$ & - & $?$ & $\begin{array}{l}\text { Dead } \\
\text { Dead }\end{array}$ \\
\hline Reinicke (41) & 1977 & M & 59 & Hemochromatosis & - & Autopsy & Dead \\
\hline Rabson (23) & 1975 & $M$ & 55 & Hemochromatosis & $?$ & $?$ & Dead \\
\hline Rabson (22) & 1972 & $\mathrm{~F}$ & 57 & $\begin{array}{l}\text { Cirrhosis } \\
\text { Hemochromatosis }\end{array}$ & $\begin{array}{l}\text { Metronidazole } \\
\text { Penicillin } \\
\text { Tetracycline }\end{array}$ & Autopsy & Dead \\
\hline Mollaret (40) & 1971 & $\mathrm{~F}$ & 69 & Diabetes & Penicillin & Autopsy & Dead \\
\hline Bloquiaux (39) & 1968 & M & 40 & None & $\begin{array}{l}\text { Kanamicine } \\
\text { Penicillin } \\
\text { Ampicillin }\end{array}$ & Laparotomy & Survived \\
\hline Hassig (38) & 1949 & M & $\begin{array}{l}60 \\
69\end{array}$ & $\begin{array}{l}\text { Cirrhosis } \\
\text { Cirrhosis }\end{array}$ & $\begin{array}{l}- \\
- \\
\end{array}$ & $\begin{array}{l}\text { Autopsy } \\
\text { Autopsy }\end{array}$ & $\begin{array}{l}\text { Dead } \\
\text { Dead }\end{array}$ \\
\hline
\end{tabular}

M Male; F Female

proved following intravenous antibiotics for 21 days and oral trimethoprim-sulfamethoxazole (160 mg/800 mg bid) subsequently for two weeks. A subsequent visit revealed an improved clinical condition and a ferritin level returned to normal. Complete resolution of hepatic lesions was documented at the end of treatment by ultrasound study done at follow-up one month after the patient's discharge from the hospital.

\section{DISCUSSION}

$Y$ enterocolitica infection may cause several clinical syndromes. Apart from the gastrointestinal manifestations, several extraintestinal symptoms are known to occur in the weeks following acute infection. Erythema nodosum, Stevens-Johnson syndrome and arthritis have been described, especially in HLA-B27-positive individuals (5). Numerous other complications may occur. These include cellulitis (1), pyomyositis (9), pneumonia (10), pulmonary abscess (11), and endocarditis (12-14); rarely, neurologic (brachial plexus neuropathy and myelitis) (15), and nephrologic complications (glomerulonephritis) $(16,17)$ and pharyngitis (18) have been reported.

Septicemia is a rare complication which carries a poor prognosis with a mortality ranging from 34 (1) to $50 \%$ (3). Certain predisposing factors seem to favour septicemia. Children $(19,20)$ and adults past the fifth decade $(21,22)$ are more subject to septicemia. As in the present patient, diabetic individuals are at greater risk $(1,4)$. Immunosuppressive therapy, blood dyscrasias and cirrhosis are other well known states favouring septicemia $(1,4)$.

All patients with septicemia should be screened for iron overload. Rabson (23) first postulated an association between bacterial infections and the enhancing role of iron. Several large series $(1,24)$ and case reports $(8,25-27)$ have confirmed an association between septicemia due to $Y$ enterocolitica and iron overload. Several hypotheses have been postulated. $Y$ enterocolitica, which 
has no iron-binding ligands, may proliferate if the exogenous supply of iron is increased (6). Furthermore, the growth of $Y$ enterocolitica is enhanced in vitro (28) and its virulence increased strikingly in experimental (28) and probably human (30) infections with the use of desferoxamine which provides easily used iron for the bacteria. As well, iron appears to decrease the bactericidal and bacteriostatic activity of the serum and decreases host defence mechanisms (7). However, in Bouza's review (1), 22\% of cases occurred in previously healthy individuals. Ferritin is a well known acute phase reactant, and the reversible increased level in the present case may be due to this fact.

This particular patient, however, had increased iron stores on liver biopsy, reflecting a degree of liver iron overload for which there was no clear explanation and which probably contributed to the occurrence of yersinia infection.

Hepatic complications from $Y$ enterocolitica are of several types. Cholangitis has been reported (31) as well as cases of acute necrotizing hepatitis and granulomatous hepatitis (32-34). Few reports of liver abscesses exist in the literature $(23,24,38-49)$ (Table 1). These may present in two

\section{REFERENCES}

1. Bouza E, Dominguez A, Meseguer M, et al. Yersinia enterocolitica septicemia. Am J Clin Pathol 1980;74:404-9.

2. Cover T, Aber R. Yersinia enterocolitica. N Engl J Med 1989;321:16-24.

3. Toma S, Lafleur L, Deidrick VR. Canadian experience with Yersinia enterocolitica (1966-1977). Contrib Microbiol Immunol 1979;5:144-9.

4. Mollaret HH. L'infection humaine à Yersinia enterocolitica en 1970, à la lumière de 642 cas récents. Pathol Biol 1971;19:189-205.

5. Larsen JH. The spectrum of clinical manifestations of infections with Yersinia enterocolitica and their pathogenesis. Contrib Microbiol Immunol 1979:5:257-69

6. Foberg U, Fryden A, Kihlshöm E, Persson K, Weiland O, Yersimia enterocolitica septicemia: Clinical and microbiological aspects. Scand ] Infect Dis 1986;18:269-79.

7. Leighton P, MacSween HM. Yersinia forms: solitary or multiple. Solitary abscesses present with nonspecific symptoms such as weight loss and right upper quadrant pain. Multiple liver abscesses usually follow septicemia and present with jaundice and hepatomegaly as in this case. Development of hepatic abscess due to $Y$ enterocolitica infection is usually associated with a poor prognosis (7). However, cases reported from the past decade have shown a fall in the number of deaths associated with this condition. Several reasons may be postulated.

The advent of better imaging techniques is probably the greatest contributing factor. In earlier reports, diagnosis was usually done at autopsy. With recent developments in nuclear medicine and ultrasound, earlier diagnosis is now possible and appropriate therapy can be instituted. Microbiological studies have identified the antibiotic susceptibility of $\mathrm{Y}$ enterocolitica. The organism is usually susceptible in vitro to aminoglycosides, chloramphenicol, tetracycline, trimethoprim-sulfamethoxazole, the third generation cephalosporins $(35,36)$ and the new quinolones $(2,50)$. Better selection of antimicrobial regimen is thereby possible and may be an additional factor explaining the better outcome of patients. The drug of choice

hepatic abscesses subsequent to long term iron therapy. JAMA

1987:257:964-5.

8. Bockus HL. Gastroenterology, Vol 5, 4th edn. Philadelphia: WB Saunders, 1985:3203-21

9. Brennessel D, Robbins N, Hindman S. Pyomyosit is caused by Yersinia enterocolitica. J Clin Microbiol 1984;20:293-4.

10. Portnoy D, Martinez LA. Yersinia enterocolitica septicemia with pneumonia. Can Med Assoc I 1979;120:61-2.

11. Sebes Jl, Mabry EH, Rabinowitz JG. Lung abscess and osteomyelitis of rib due to Yersinia enterocolitica. Chest 1976;69:546-8.

12. Quinsat D, Harle JR, Fosse T, et al. Endocardite à Yersinia enterocolitica serotype 0:8. Presse Med 1986;15:487.

13. Green HT, Morris AI, Haqqani MT, Nair P. Infective endocarditis due to Yersinia enterocolitica. J Infect 1983;7:267-9. for systemic infection has not yet been identified. Gentamicin $5 \mathrm{mg} / \mathrm{kg} /$ day intravenously, chloramphenicol 50 $\mathrm{mg} / \mathrm{kg} /$ day or a third generation ceph. alosporin should be beneficial (36). Relapse may occur following treatment (6). Prolonged treatment (six weeks) may be continued on an outpatient basis using trimethoprim-sulfamethoxazole.

In conclusion, patients presenting with $Y$ enterocolitica septicemia should be screened systematically for predisposing conditions, most notably diabetes and iron overload. Increased awareness of the several complications which may follow could lead to an earlier diagnosis. When hepatic abscesses are suspected, abdominal ultrasounds and computerized axial tomography scan will provide important diagnostic information. Treatment should be prolonged for hepatic abscesses - a minimum of six weeks or until com. plete radiologic resolution of abscesses. Earlier diagnosis and appropriate antibiotic selection will probably alter the prognosis of patients with $Y$ entero. colitica abscesses.

ACKNOWLEDGEMENTS: The author thanks Mrs Isabelle Guyon for secretarial help.

14. Appelbaum JS, Wilding G, Morse L. Yersinia enterocolitica endocarditis. Arch Intern Med 1983;143:2150-1.

15. Sotaniemi KA. Neurologic complications associated with yersiniosis. Neurology 1983;33:95-7.

16. Denneberg T, Friedberg M, Samuelson $\mathrm{T}$, Winblad S. Glomerulonephritis in infections with Yersinia enterocolitica serotype 3. Acta Med Scand 1981;209:97-101.

17. Korpela M, Mustonen A, Pasternack A, Leinikki P. Urinary tract and renal findings in acute yersinia infections. Acta Med Scand 1986;220:471-6.

18. Tacket CO, Davis BR, Carter GP, Randolf JF, Cohen ML. Yersinia enterocolitica pharyngitis.

Ann Intern Med 1983;99:40-2.

19. Kohl S, Jacobson JA, Nahmias A Yersinia enterocolitica infections in children. J Pediatr 1976;89:77-9.

20. Caplan LM, Dobson ML, Dorkin H. Yersinia enterocolitica septicemia. Am J Clin Parhol 1978;69:189-92. 
21. Narasimhan SL, Schieven BC, Campsall EWR. Septicemia caused by Yersinia enterocolitica. Can Med Assoc ] 1978;118:682.

22. Josefsson K, Lindberg A. Fatal Yersinia enterocolitica septicemia. Scand J Infect Dis $1975 ; 7: 76-7$.

23. Rabson AR, Koomhof HJ, Notman J, Maxwell WG. Hepatosplenic abscesses due to Yersinia enterocolitica. Br Med J $1972 ; 4: 341$.

24. Rabson AR, Hallett AF, Koornhof HJ. Generalized Yersinia enterocolitica infec tion. J Infect Dis 1975;131:447-51.

25. Melby K, Slordahl S, Gutteberg TJ, Nordbo SA. Septicaemia due to Yersinia enterocolitica after oral overdoses of iron. Br Med J 1982;285:467-8.

26. Chiu HY, Flynn DM, Hoffbrand AV. Infection with Yersinia enterocolitica in patients with iron overload. Br Med J 1986;292:97.

27. Abbott M, Galloway A, Cunningham IL. Haemochromatosis presenting with a double yersinia infection. J Infect 1986;13:143-5.

28. Brock JH, Ng J. The effect of desferrioxamine on the growth of $S$ aureus, Yersinia enterocolitica and $S$ faecalis in human serum: Uptake of desferrioxamine band iron. FEMS Microbiol Lett 1983;20:439-42.

29. Robins-Browne RM, Prpic JK. Effects of $n$ and desferrioxamine on infection with $Y$ enterocolitica. Infect Immunol 1985;47:774-9.

30. Gallant $T$, Freedman $M H$, Vellend $H$, Francombe WH. Yersinia sepis in patients with iron overload treated with deferoxamine. N Engl J Med 1986;314:1643

31. Rush O, Sayed HI, Whitby JL, Wall WI. Cholangitis caused by Yersinia enterocolitica. Can Med Assoc J
1980;123:1017-8.

32. Saebo A. Liver affection associated with Yersinia enterocolitica infection. Acta Chir Scand 1977;143:445-50.

33. Dubois A, Gervais C, Arich C, et al. Manifestations hépatiques des yersinioses. Nouv Presse Med 1982;11:1619-21.

34. Worthington MG, O'Donnell KF, Dowling JJ, Murphy T, Whitmore EL. Granulomatous hepatat is in Yersinia enterocolitica bacteraemia. J Infect 1984:9:170-3

35. Bottone E]. Yersinia enterocolitica: A panoramic view of a charismatic microorganism. CRC Crit Rev Microbiol 1977;5:211-41.

36. Scribner RK, Marks MI, Weber A. Comparative in vitro activities of seven new beta-lactam antibiotics. Antimicrob Agents Chemother 1982;22:140.

37. Mandell G, Douglas G, Bennett J. Principles and Practice of Infectious Diseases, 2 nd edn. New York: John Wiley \& Sons, 1985:1300.

38. Hassig A, Karrer J, Pusterla F. Uber Pseudotuber Kulose beim Menschen. Schweiz Med Wochenschr 1949;79:971-3.

39. Bloquiaux W. Multipele Lever Abescessen door Yersinia enterocolitica. Tijdschr Gastroenterol 1968;1 1:578-83.

40. Mollaret $\mathrm{HH}$, Omland T, Henriksen SD, Baeroe PR, Rykner G, Scavizzi M. Les septicémies humaines à Yersinia enterocolitica. A propos de dix-sept cas récents. Presse Med 1971;79:345-8.

41. Reinicke V, Korner B. Fulminant septicemia caused by Yersinia enterocolitica. Scand J Infect Dis 1977;9:249-51.

42. Mantse L, West J, Cosman $\mathrm{HH}$, Mullens JE. Liver abscesses due to Yersinia enterocolitica. Can Med Assoc ] 1978;119:922-3.
43. Ryan M, Burke $P$, Nevinger QT, Shah N. Hepatic abscesses due to Yersinia enterocolitica. Am J Dis Child 1979;133:961.

44. Imhoof B, Auckenthaler R. Septicemia caused by Yersinia enterocolitica: Report of a case (FR). Schweiz Med Wochenschr 1980;110:1115-7.

45. Viteri A, Paxton HH, May JL, Ramesh GS, Roberts JW. Hepatic abscesses due to Yersinia enterocolitica without bacterimia. Gastroenterology $1981 ; 81: 592-3$.

46. Fothergill J, Mullira AE, Skirrow MB. Liver abscess due to an unusual strain of Yersinia enterocolitica. Postgrad Med J 1982;58:371-2.

47. Van Lier TA, Lagaaij MG, Ross J. A patient with liver abscesses due to infection with Yersinia enterocolitica. Ned Tijdschr Geneeskd 1983;127:293-5. (Dutch)

48. Beeching NJ, Hart $\mathrm{HH}$, Synek BN, Bremner DA. A patient with hemosiderosis and multiple liver abscesses due to Yersinia enterocolitica. Pathology 1985;17:530-2.

49. Abalain-Colloc ML, Mottier D, Masure O, LeNeel MD, Chastel C. Abcès hépatique primitif à Yersinia enterocolitica. Semin Hop Paris 1986;62:1637-8.

50. Neu H. Quinolones: A new class of antimicrobial agents with wide potential uses. Med Clin North Am 1988;72:623-36

51. Khanna R, Levendoglu H. Liver abscess due to Yersinia enterocolitica: Case report and review of the literature. Dig Dis Sci 1989;34:636-9.

52. Cauchie P, Vincken W, Peeters O, Charles K. Hemochromatosis and Yersinia enterocolitica septicemia. Dig Dis Sci 1987;32:1438. 


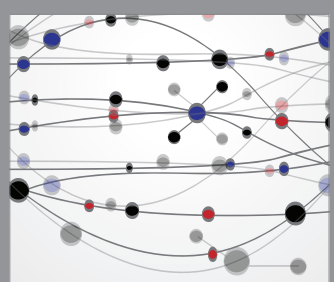

The Scientific World Journal
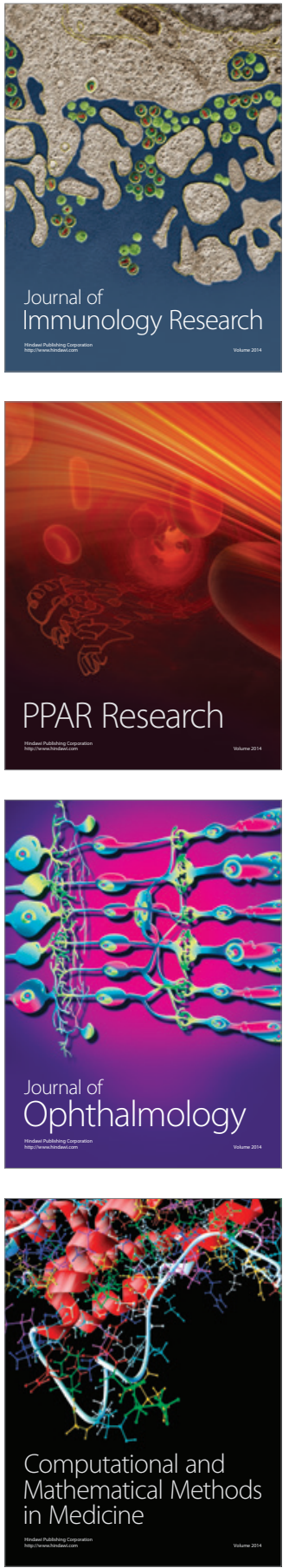

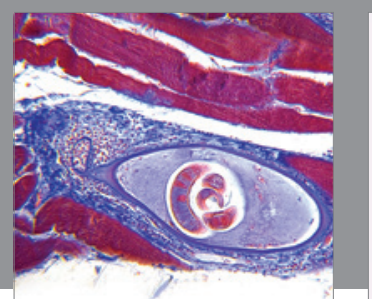

Gastroenterology Research and Practice

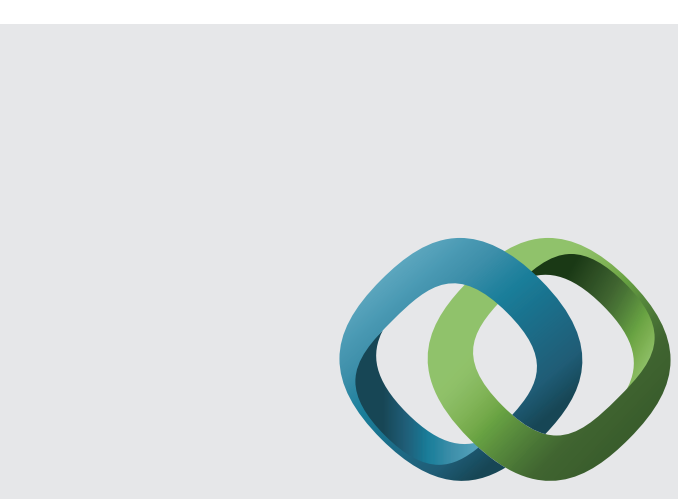

\section{Hindawi}

Submit your manuscripts at

http://www.hindawi.com
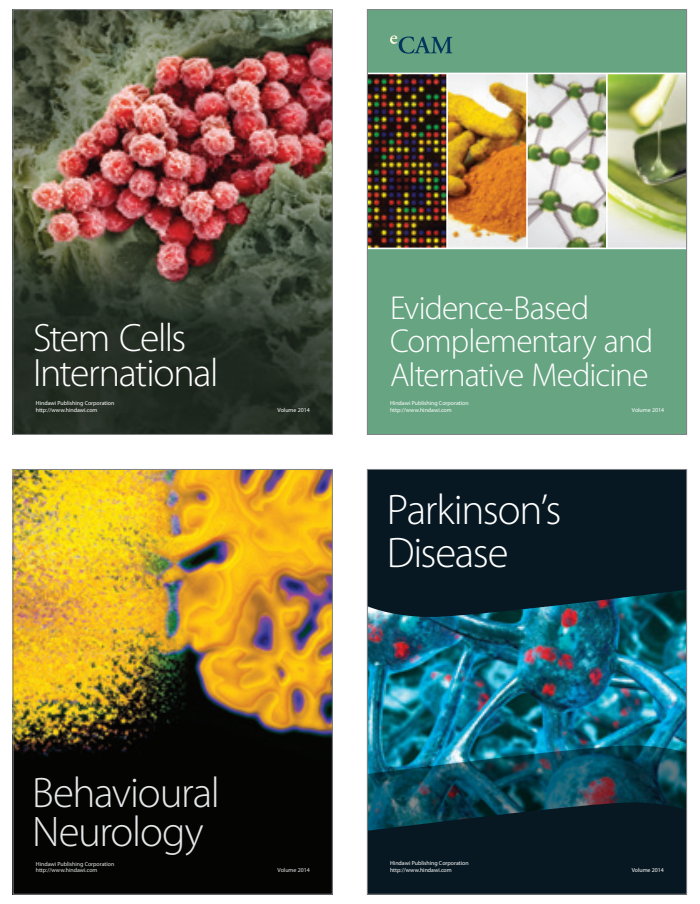
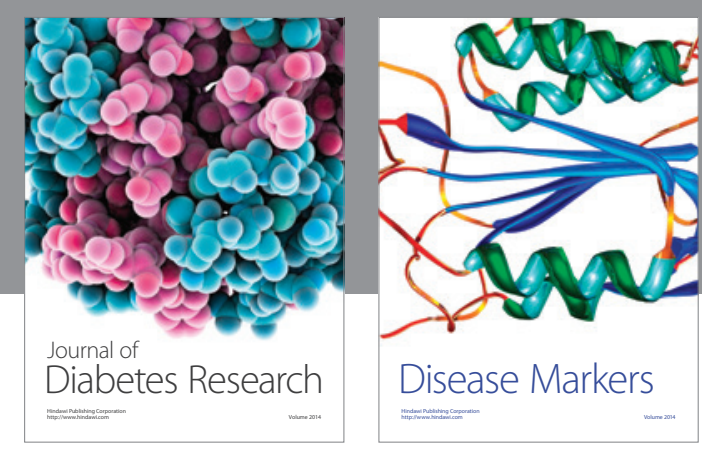

Disease Markers
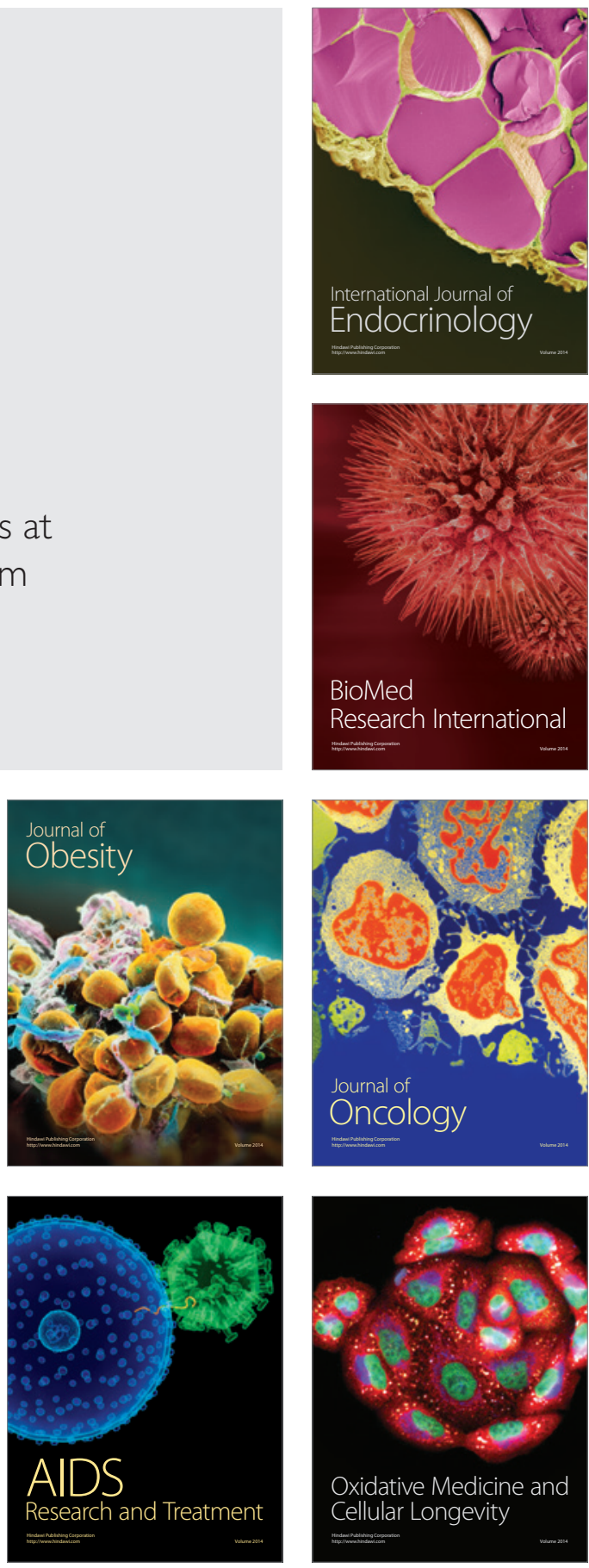